\title{
Ionotropic glutamate receptors in GtoPdb v.2021.3
}

Bernhard Bettler ${ }^{1}$, Graham L. Collingridge ${ }^{2}$, Ray Dingledine ${ }^{3}$, Stephen F. Heinemann ${ }^{4}$, Michael Hollmann $^{5}$, Juan Lerma ${ }^{6}$, David Lodge ${ }^{2}$, Mark Mayer ${ }^{7}$, Masayoshi Mishina $^{8}$, Christophe Mulle ${ }^{9}$, Shigetada Nakanishi ${ }^{10}$, Richard Olsen ${ }^{11}$, Stephane Peineau ${ }^{2}$, John A. Peters ${ }^{12}$, Peter Seeburg ${ }^{13}$, Michael Spedding ${ }^{14}$ and Jeffrey C. Watkins ${ }^{2}$

1. University of Basel, Switzerland

2. University of Bristol, UK

3. Emory University, USA

4. Salk Institute, USA

5. Ruhr University Bochum, Germany

6. Universidad Miguel Hernández, Spain

7. National Institutes of Health, USA

8. University of Tokyo, Japan

9. Université Bordeaux 2, France

10. Kyoto University Faculty of Medicine, Japan

11. University of California Los Angels, USA

12. University of Dundee, UK

13. Max Planck Institute for Medical Research, Germany

14. Spedding Research Solutions SARL, France

\begin{abstract}
The ionotropic glutamate receptors comprise members of the NMDA (N-methyl-D-aspartate), AMPA ( $\alpha$-amino-3-hydroxy-5-methyl-4-isoxazoleproprionic acid) and kainate receptor classes, named originally according to their preferred, synthetic, agonist [35, 92, 155]. Receptor heterogeneity within each class arises from the homo-oligomeric, or hetero-oligomeric, assembly of distinct subunits into cation-selective tetramers. Each subunit of the tetrameric complex comprises an extracellular amino terminal domain (ATD), an extracellular ligand binding domain (LBD), 3 TM domains (M1, M3 and M4), a channel lining re-entrant 'p-loop' (M2) located between M1 and M3 and an intracellular carboxy- terminal domain (CTD) [99, 68, 107, 155, 82]. The X-ray structure of a homomeric ionotropic glutamate receptor (GluA2- see below) has recently been solved at $3.6 \AA$ resolution [143] and although providing the most complete structural information current available may not representative of the subunit arrangement of, for example, the heteromeric NMDA receptors [71]. It is beyond the scope of this supplement to discuss the pharmacology of individual ionotropic glutamate receptor isoforms in detail; such information can be gleaned from [35, 66, 31, 77, 42, 114, $24,65,155,112,113,162]$. Agents that discriminate between subunit isoforms are, where appropriate, noted in the tables and additional compounds that distinguish between receptor isoforms are indicated in the text below.
\end{abstract}

The classification of glutamate receptor subunits has been re-addressed by NC-IUPHAR [28]. The scheme developed recommends a nomenclature for ionotropic glutamate receptor subunits that is adopted here.

\section{NMDA receptors}

NMDA receptors assemble as obligate heteromers that may be drawn from GluN1, GluN2A, GluN2B, GluN2C, GluN2D, GluN3A and GluN3B subunits. Alternative splicing can generate eight isoforms of GluN1 with differing pharmacological properties. Various splice variants of GluN2B, 2C, 2D and GluN3A have also been reported. Activation of NMDA receptors containing GluN1 and GluN2 subunits requires the binding of two agonists, glutamate to the S1 and S2 regions of the GluN2 subunit and glycine to S1 and S2 regions of the GluN1 subunit [41, 25]. The minimal requirement for efficient functional expression of NMDA receptors in vitro is a di-heteromeric assembly of GluN1 and at least one GluN2 subunit variant, as a dimer of heterodimers arrangement in the extracellular domain [48, 99, 71]. However, more complex tri-heteromeric assemblies, incorporating multiple subtypes of GluN2 subunit, or GluN3 subunits, can be generated in vitro and occur in vivo. The 
NMDA receptor channel commonly has a high relative permeability to $\mathrm{Ca}^{2+}$ and is blocked, in a voltage-dependent manner, by $\mathrm{Mg}^{2+}$ such that at resting potentials the response is substantially inhibited.

\section{AMPA and Kainate receptors}

AMPA receptors assemble as homomers, or heteromers, that may be drawn from GluA1, GluA2, GluA3 and GluA4 subunits. Transmembrane AMPA receptor regulatory proteins (TARPs) of class I (i.e. $\gamma 2, \gamma 3, \gamma 4$ and $\gamma 8$ ) act, with variable stoichiometry, as auxiliary subunits to AMPA receptors and influence their trafficking, single channel conductance gating and pharmacology (reviewed in [43, $103,153,64])$. Functional kainate receptors can be expressed as homomers of GluK1, GluK2 or GluK3 subunits. GluK1-3 subunits are also capable of assembling into heterotetramers (e.g. GluK1/K2; [87, 119, 118]). Two additional kainate receptor subunits, GluK4 and GluK5, when expressed individually, form high affinity binding sites for kainate, but lack function, but can form heteromers when expressed with GluK1-3 subunits (e.g. GluK2/K5; reviewed in [119, 65, 118]). Kainate receptors may also exhibit 'metabotropic' functions [87, 131]. As found for AMPA receptors, kainate receptors are modulated by auxiliary subunits (Neto proteins, $[118,88]$ ). An important function difference between AMPA and kainate receptors is that the latter require extracellular $\mathrm{Na}^{+}$ and $\mathrm{Cl}^{-}$for their activation $[11,120]$. RNA encoding the GluA2 subunit undergoes extensive RNA editing in which the codon encoding a p-loop glutamine residue (Q) is converted to one encoding arginine (R). This Q/R site strongly influences the biophysical properties of the receptor.

Recombinant AMPA receptors lacking RNA edited GluA2 subunits are: (1) permeable to $\mathrm{Ca}^{2+}$; (2) blocked by intracellular polyamines at depolarized potentials causing inward rectification (the latter being reduced by TARPs); (3) blocked by extracellular argiotoxin and joro spider toxins and (4) demonstrate higher channel conductances than receptors containing the edited form of GluA2 [139, 63]. GluK1 and GluK2, but not other kainate receptor subunits, are similarly edited and broadly similar functional characteristics apply to kainate receptors lacking either an RNA edited GluK1, or GluK2, subunit $[87,118]$. Native AMPA and kainate receptors displaying differential channel conductances, $\mathrm{Ca}^{2+}$ permeabilites and sensitivity to block by intracellular polyamines have been identified [30,63, 91]. GluA1-4 can exist as two variants generated by alternative splicing (termed 'flip' and 'flop') that differ in their desensitization kinetics and their desensitization in the presence of cyclothiazide which stabilises the nondesensitized state. TARPs also stabilise the non-desensitized conformation of AMPA receptors and facilitate the action of cyclothiazide [103]. Splice variants of GluK1-3 also exist which affects their trafficking [87, 118].

\section{Contents}

This is a citation summary for Ionotropic glutamate receptors in the Guide to Pharmacology database (GtoPdb). It exists purely as an adjunct to the database to facilitate the recognition of citations to and from the database by citation analyzers. Readers will almost certainly want to visit the relevant sections of the database which are given here under database links.

GtoPdb is an expert-driven guide to pharmacological targets and the substances that act on them. GtoPdb is a reference work which is most usefully represented as an on-line database. As in any publication this work should be appropriately cited, and the papers it cites should also be recognized. This document provides a citation for the relevant parts of the database, and also provides a reference list for the research cited by those parts. For further details see [16].

Please note that the database version for the citations given in GtoPdb are to the most recent preceding version in which the family or its subfamilies and targets were substantially changed. The links below are to the current version. If you need to consult the cited version, rather than the most recent version, please contact the GtoPdb curators.

\section{Database links}

Ionotropic glutamate receptors

https://www.guidetopharmacology.org/GRAC/FamilyDisplayForward?familyId=75

Channels and Subunits

GluA1

https://www.guidetopharmacology.org/GRAC/ObjectDisplayForward?objectId=444

GluA2

https://www.guidetopharmacology.org/GRAC/ObjectDisplayForward?objectId=445 GluA3

https://www.guidetopharmacology.org/GRAC/ObjectDisplayForward?objectId=446 GluA4

https://www.guidetopharmacology.org/GRAC/ObjectDisplayForward?objectId=447 
GluD1

https://www.guidetopharmacology.org/GRAC/ObjectDisplayForward?objectId=448 GluD2

https://www.guidetopharmacology.org/GRAC/ObjectDisplayForward?objectId=449 GluK1

https://www.guidetopharmacology.org/GRAC/ObjectDisplayForward?objectId=450 GluK2

https://www.guidetopharmacology.org/GRAC/ObjectDisplayForward?objectId=451 GluK3

https://www.guidetopharmacology.org/GRAC/ObjectDisplayForward?objectId=452 GluK4

https://www.guidetopharmacology.org/GRAC/ObjectDisplayForward?objectId=453 GluK5

https://www.guidetopharmacology.org/GRAC/ObjectDisplayForward?objectId=454 GluN1

https://www.guidetopharmacology.org/GRAC/ObjectDisplayForward?objectId=455 GluN2A

https://www.guidetopharmacology.org/GRAC/ObjectDisplayForward?objectId=456 GluN2B

https://www.guidetopharmacology.org/GRAC/ObjectDisplayForward?objectId=457 GluN2C

https://www.guidetopharmacology.org/GRAC/ObjectDisplayForward?objectId=458 GluN2D

https://www.guidetopharmacology.org/GRAC/ObjectDisplayForward?objectId=459 GluN3A

https://www.guidetopharmacology.org/GRAC/ObjectDisplayForward?objectId=460 GluN3B

https://www.guidetopharmacology.org/GRAC/ObjectDisplayForward?objectId=461

\section{References}

1. Acker TM, Yuan H, Hansen KB, Vance KM, Ogden KK, Jensen HS, Burger PB, Mullasseril P, Snyder JP and Liotta DC et al.. (2011) Mechanism for noncompetitive inhibition by novel GluN2C/D N-methyl-D-aspartate receptor subunit-selective modulators. Mol Pharmacol 80: 78295 [PMID:21807990]

2. Aicher SA, Sharma S and Mitchell JL. (2002) Co-localization of AMPA receptor subunits in the nucleus of the solitary tract in the rat. Brain Res 958: 454-8 [PMID:12470884]

3. Antal M, Fukazawa Y, Eördögh M, Muszil D, Molnár E, Itakura M, Takahashi M and Shigemoto R. (2008) Numbers, densities, and colocalization of AMPA- and NMDA-type glutamate receptors at individual synapses in the superficial spinal dorsal horn of rats. J Neurosci 28: 9692-701 [PMID:18815255]

4. Atlason PT, Scholefield CL, Eaves RJ, Mayo-Martin MB, Jane DE and Molnár E. (2010) Mapping the ligand binding sites of kainate receptors: molecular determinants of subunit-selective binding of the antagonist [3H]UBP310. Mol Pharmacol 78: 1036-45 [PMID:20837679]

5. Auberson YP, Allgeier H, Bischoff S, Lingenhoehl K, Moretti R and Schmutz M. (2002) 5Phosphonomethylquinoxalinediones as competitive NMDA receptor antagonists with a preference for the human 1A/2A, rather than 1A/2B receptor composition. Bioorg Med Chem Lett 12: 1099-102 [PMID:11909726]

6. Bassani S, Valnegri P, Beretta F and Passafaro M. (2009) The GLUR2 subunit of AMPA receptors: synaptic role. Neuroscience 158: 55-61 [PMID:18977416]

7. Beneyto M, Kristiansen LV, Oni-Orisan A, McCullumsmith RE and Meador-Woodruff JH. (2007) Abnormal glutamate receptor expression in the medial temporal lobe in schizophrenia and mood disorders. Neuropsychopharmacology 32: 1888-902 [PMID:17299517]

8. Bettini E, Sava A, Griffante C, Carignani C, Buson A, Capelli AM, Negri M, Andreetta F, SenarSancho SA and Guiral L et al.. (2010) Identification and characterization of novel NMDA receptor antagonists selective for NR2A- over NR2B-containing receptors. J Pharmacol Exp Ther 335: 636-44 [PMID:20810618]

9. Bochet P, Audinat E, Lambolez B, Crépel F, Rossier J, Iino M, Tsuzuki K and Ozawa S. (1994) Subunit composition at the single-cell level explains functional properties of a glutamate-gated channel. Neuron 12: 383-8 [PMID:7509161]

10. Boulter J, Hollmann M, O'Shea-Greenfield A, Hartley M, Deneris E, Maron C and Heinemann S. (1990) Molecular cloning and functional expression of glutamate receptor subunit genes. Science 249: 1033-7 [PMID:2168579]

11. Bowie D. (2010) Ion-dependent gating of kainate receptors. J Physiol (Lond.) 588: 67-81 [PMID:19822544]

12. Brand-Schieber E, Lowery SL and Werner P. (2004) Select ionotropic glutamate AMPA/kainate 
receptors are expressed at the astrocyte-vessel interface. Brain Res 1007: 178-82 [PMID:15064149]

13. Brand-Schieber E and Werner P. (2003) (+/-)-Alpha-amino-3-hydroxy-5-methylisoxazole-4propionic acid and kainate receptor subunit expression in mouse versus rat spinal cord white matter: similarities in astrocytes but differences in oligodendrocytes. Neurosci Lett 345: 126-30 [PMID:12821187]

14. Brand-Schieber E and Werner P. (2003) AMPA/kainate receptors in mouse spinal cord cellspecific display of receptor subunits by oligodendrocytes and astrocytes and at the nodes of Ranvier. Glia 42: 12-24 [PMID:12594733]

15. Brusa R, Zimmermann F, Koh DS, Feldmeyer D, Gass P, Seeburg PH and Sprengel R. (1995) Early-onset epilepsy and postnatal lethality associated with an editing-deficient GluR-B allele in mice. Science 270: 1677-80 [PMID:7502080]

16. Buneman P, Christie G, Davies JA, Dimitrellou R, Harding SD, Pawson AJ, Sharman JL and Wu Y. (2020) Why data citation isn't working, and what to do about it Database $\mathbf{2 0 2 0}$ [PMID:32367113]

17. Burnashev N, Monyer H, Seeburg PH and Sakmann B. (1992) Divalent ion permeability of AMPA receptor channels is dominated by the edited form of a single subunit. Neuron 8: 189-98 [PMID:1370372]

18. Caicedo A, Zucchi B, Pereira E and Roper SD. (2004) Rat gustatory neurons in the geniculate ganglion express glutamate receptor subunits. Chem Senses 29: 463-71 [PMID:15269118]

19. Cantrell BE, Zimmerman DM, Monn JA, Kamboj RK, Hoo KH, Tizzano JP, Pullar IA, Farrell LN and Bleakman D. (1996) Synthesis of a series of aryl kainic acid analogs and evaluation in cells stably expressing the kainate receptor humGluR6. J Med Chem 39: 3617-24 [PMID:8809152]

20. Cavara NA and Hollmann M. (2008) Shuffling the deck anew: how NR3 tweaks NMDA receptor function. Mol Neurobiol 38: 16-26 [PMID:18654865]

21. Chatterton JE, Awobuluyi M, Premkumar LS, Takahashi H, Talantova M, Shin Y, Cui J, Tu S, Sevarino KA and Nakanishi N et al.. (2002) Excitatory glycine receptors containing the NR3 family of NMDA receptor subunits. Nature 415: 793-8 [PMID:11823786]

22. Chazot PL, Reiss C, Chopra B and Stephenson FA. (1998) [3H]MDL 105,519 binds with equal high affinity to both assembled and unassembled NR1 subunits of the NMDA receptor. Eur J Pharmacol 353: 137-40 [PMID:9721050]

23. Chen LW, Tse YC, Li C, Guan ZL, Lai CH, Yung KK, Shum DK and Chan YS. (2006) Differential expression of NMDA and AMPA/KA receptor subunits in the inferior olive of postnatal rats. Brain Res 1067: 103-14 [PMID:16376317]

24. Chen PE, Geballe MT, Katz E, Erreger K, Livesey MR, O'Toole KK, Le P, Lee CJ, Snyder JP and Traynelis SF et al.. (2008) Modulation of glycine potency in rat recombinant NMDA receptors containing chimeric NR2A/2D subunits expressed in Xenopus laevis oocytes. J Physiol (Lond.) 586: 227-45 [PMID:17962328]

25. Chen PE and Wyllie DJ. (2006) Pharmacological insights obtained from structure-function studies of ionotropic glutamate receptors. Br J Pharmacol 147: 839-53 [PMID:16474411]

26. Chopra B, Chazot PL and Stephenson FA. (2000) Characterization of the binding of two novel glycine site antagonists to cloned NMDA receptors: evidence for two pharmacological classes of antagonists. Br J Pharmacol 130: 65-72 [PMID:10780999]

27. Chun YH, Frank D, Lee JS, Zhang Y, Auh QS and Ro JY. (2008) Peripheral AMPA receptors contribute to muscle nociception and c-fos activation. Neurosci Res 62: 97-104 [PMID:18655811]

28. Collingridge GL, Olsen RW, Peters J and Spedding M. (2009) A nomenclature for ligand-gated ion channels. Neuropharmacology 56: 2-5 [PMID:18655795]

29. Corbett EK, Saha S, Deuchars J, McWilliam PN and Batten TF. (2003) Ionotropic glutamate receptor subunit immunoreactivity of vagal preganglionic neurones projecting to the rat heart. Auton Neurosci 105: 105-17 [PMID:12798207]

30. Cull-Candy S, Kelly L and Farrant M. (2006) Regulation of Ca2+-permeable AMPA receptors: synaptic plasticity and beyond. Curr Opin Neurobiol 16: 288-97 [PMID:16713244]

31. Cull-Candy SG and Leszkiewicz DN. (2004) Role of distinct NMDA receptor subtypes at central synapses. Sci STKE 2004: re16 [PMID:15494561]

32. Deng YP, Xie JP, Wang HB, Lei WL, Chen Q and Reiner A. (2007) Differential localization of the GluR1 and GluR2 subunits of the AMPA-type glutamate receptor among striatal neuron types in rats. J Chem Neuroanat 33: 167-92 [PMID:17446041]

33. Deur C, Agrawal AK, Baum H, Booth J, Bove S, Brieland J, Bunker A, Connolly C, Cornicelli J and Dumin J et al.. (2007) N-(6,7-dichloro-2,3-dioxo-1,2,3,4-tetrahydroquinoxalin-5-yl)-Nalkylsulfonamides as peripherally restricted N-methyl-D-aspartate receptor antagonists for the treatment of pain. Bioorg Med Chem Lett 17: 4599-603 [PMID:17562362]

34. Dijk F and Kamphuis W. (2004) Ischemia-induced alterations of AMPA-type glutamate receptor subunit. Expression patterns in the rat retina--an immunocytochemical study. Brain Res 997: 207-21 [PMID:14706873] 
35. Dingledine R, Borges K, Bowie D and Traynelis SF. (1999) The glutamate receptor ion channels. Pharmacol Rev 51: 7-61 [PMID:10049997]

36. Douyard J, Shen L, Huganir RL and Rubio ME. (2007) Differential neuronal and glial expression of GluR1 AMPA receptor subunit and the scaffolding proteins SAP97 and 4.1N during rat cerebellar development. J Comp Neurol 502: 141-56 [PMID:17335044]

37. Dracheva S, Byne W, Chin B and Haroutunian V. (2008) Ionotropic glutamate receptor mRNA expression in the human thalamus: absence of change in schizophrenia. Brain Res 1214: 23-34 [PMID:18462708]

38. Dracheva S, McGurk SR and Haroutunian V. (2005) mRNA expression of AMPA receptors and AMPA receptor binding proteins in the cerebral cortex of elderly schizophrenics. J Neurosci Res 79: 868-78 [PMID:15696539]

39. Dravid SM, Erreger K, Yuan H, Nicholson K, Le P, Lyuboslavsky P, Almonte A, Murray E, Mosely $\mathrm{C}$ and Barber J et al.. (2007) Subunit-specific mechanisms and proton sensitivity of NMDA receptor channel block. J Physiol (Lond.) 581: 107-28 [PMID:17303642]

40. Edman S, McKay S, Macdonald LJ, Samadi M, Livesey MR, Hardingham GE and Wyllie DJ. (2012) TCN 201 selectively blocks GluN2A-containing NMDARs in a GluN1 co-agonist dependent but non-competitive manner. Neuropharmacology 63: 441-9 [PMID:22579927]

41. Erreger K, Chen PE, Wyllie DJ and Traynelis SF. (2004) Glutamate receptor gating. Crit Rev Neurobiol 16: 187-224 [PMID:15701057]

42. Erreger K, Geballe MT, Kristensen A, Chen PE, Hansen KB, Lee CJ, Yuan H, Le P, Lyuboslavsky PN and Micale N et al.. (2007) Subunit-specific agonist activity at NR2A-, NR2B-, NR2C-, and NR2D-containing N-methyl-D-aspartate glutamate receptors. Mol Pharmacol 72: 907-20 [PMID:17622578]

43. Esteban JA. (2008) Intracellular machinery for the transport of AMPA receptors. Br J Pharmacol 153 Suppl 1: S35-43 [PMID:18026130]

44. Feng B, Tse HW, Skifter DA, Morley R, Jane DE and Monaghan DT. (2004) Structure-activity analysis of a novel NR2C/NR2D-preferring NMDA receptor antagonist: 1-(phenanthrene-2carbonyl) piperazine-2,3-dicarboxylic acid. Br J Pharmacol 141: 508-16 [PMID:14718249]

45. Fletcher EJ, Nutt SL, Hoo KH, Elliott CE, Korczak B, McWhinnie EA and Kamboj RK. (1995) Cloning, expression and pharmacological characterization of a human glutamate receptor: hGluR4. Recept Channels 3: 21-31 [PMID:8589990]

46. Frizelle PA, Chen PE and Wyllie DJ. (2006) Equilibrium constants for (R)-[(S)-1-(4-bromophenyl)-ethylamino]-(2,3-dioxo-1,2,3,4-tetrahydroquinoxalin-5-yl)-methyl]-phosphonic acid (NVPAAM077) acting at recombinant NR1/NR2A and NR1/NR2B N-methyl-D-aspartate receptors: Implications for studies of synaptic transmission. Mol Pharmacol 70: 1022-32 [PMID:16778008]

47. Fujiyama F, Kuramoto E, Okamoto K, Hioki H, Furuta T, Zhou L, Nomura S and Kaneko T. (2004) Presynaptic localization of an AMPA-type glutamate receptor in corticostriatal and thalamostriatal axon terminals. Eur J Neurosci 20: 3322-30 [PMID:15610164]

48. Furukawa H, Singh SK, Mancusso R and Gouaux E. (2005) Subunit arrangement and function in NMDA receptors. Nature 438: 185-92 [PMID:16281028]

49. Fux CM, Krug M, Dityatev A, Schuster T and Schachner M. (2003) NCAM180 and glutamate receptor subtypes in potentiated spine synapses: an immunogold electron microscopic study. Mol Cell Neurosci 24: 939-50 [PMID:14697660]

50. Gallo V, Upson LM, Hayes WP, Vyklicky L, Winters CA and Buonanno A. (1992) Molecular cloning and development analysis of a new glutamate receptor subunit isoform in cerebellum. $J$ Neurosci 12: 1010-23 [PMID:1372042]

51. Gielen M, Siegler Retchless B, Mony L, Johnson JW and Paoletti P. (2009) Mechanism of differential control of NMDA receptor activity by NR2 subunits. Nature 459: 703-7 [PMID:19404260]

52. Greger IH, Khatri L, Kong X and Ziff EB. (2003) AMPA receptor tetramerization is mediated by Q/R editing. Neuron 40: 763-74 [PMID:14622580]

53. Gryder DS, Castaneda DC and Rogawski MA. (2005) Evidence for low GluR2 AMPA receptor subunit expression at synapses in the rat basolateral amygdala. J Neurochem 94: 1728-38 [PMID:16045445]

54. Hansen KB, Ogden KK and Traynelis SF. (2012) Subunit-selective allosteric inhibition of glycine binding to NMDA receptors. J Neurosci 32: 6197-208 [PMID:22553026]

55. Hansen KB and Traynelis SF. (2011) Structural and mechanistic determinants of a novel site for noncompetitive inhibition of GluN2D-containing NMDA receptors. J Neurosci 31: 3650-61 [PMID:21389220]

56. Henson MA, Roberts AC, Pérez-Otaño I and Philpot BD. (2010) Influence of the NR3A subunit on NMDA receptor functions. Prog Neurobiol 91: 23-37 [PMID:20097255]

57. Hollmann M, Hartley M and Heinemann S. (1991) Ca2+ permeability of KA-AMPA--gated glutamate receptor channels depends on subunit composition. Science 252: 851-3 [PMID:1709304]

58. Hollmann M, O'Shea-Greenfield A, Rogers SW and Heinemann S. (1989) Cloning by functional 
expression of a member of the glutamate receptor family. Nature 342: 643-8 [PMID:2480522]

59. Horak M, Vlcek K, Chodounska H and Vyklicky L. (2006) Subtype-dependence of N-methyl-Daspartate receptor modulation by pregnenolone sulfate. Neuroscience 137: 93-102 [PMID:16257494]

60. Horning MS, Kwon B, Blakemore LJ, Spencer CM, Goltz M, Houpt TA and Trombley PQ. (2004) Alpha-amino-3-hydroxy-5-methyl-4-isoxazolepropionate receptor subunit expression in rat olfactory bulb. Neurosci Lett 372: 230-4 [PMID:15542246]

61. Hume RI, Dingledine R and Heinemann SF. (1991) Identification of a site in glutamate receptor subunits that controls calcium permeability. Science 253: 1028-31 [PMID:1653450]

62. Iino M, Koike M, Isa T and Ozawa S. (1996) Voltage-dependent blockage of Ca(2+)-permeable AMPA receptors by joro spider toxin in cultured rat hippocampal neurones. J Physiol (Lond.) 496 ( Pt 2): 431-7 [PMID:8910227]

63. Isaac JT, Ashby M and McBain CJ. (2007) The role of the GluR2 subunit in AMPA receptor function and synaptic plasticity. Neuron 54: 859-71 [PMID:17582328]

64. Jackson AC and Nicoll RA. (2011) The expanding social network of ionotropic glutamate receptors: TARPs and other transmembrane auxiliary subunits. Neuron 70: 178-99 [PMID:21521608]

65. Jane DE, Lodge D and Collingridge GL. (2009) Kainate receptors: pharmacology, function and therapeutic potential. Neuropharmacology 56: 90-113 [PMID:18793656]

66. Jane DE, Tse H-W, Skifter DA, Christie JM and Monaghan DT. (2000) Glutamate receptor ion channels: activators and inhibitors. In Handbook of Experimental Pharmacology, Pharmacology of Ionic Channel Function: Activators and Inhibitors Edited by Endo M, Kurachi Y, Mishina M: Springer: $415-478$

67. Jones BE, Tovar KR, Goehring A, Jalali-Yazdi F, Okada NJ, Gouaux E and Westbrook GL. (2019) Autoimmune receptor encephalitis in mice induced by active immunization with conformationally stabilized holoreceptors. Sci Transl Med 11 [PMID:31292262]

68. Kaczor AA and Matosiuk D. (2010) Molecular structure of ionotropic glutamate receptors. Curr Med Chem 17: 2608-35 [PMID:20491632]

69. Kamphuis W, Klooster J and Dijk F. (2003) Expression of AMPA-type glutamate receptor subunit (GluR2) in ON-bipolar neurons in the rat retina. J Comp Neurol 455: 172-86 [PMID:12454983]

70. Karakas E and Furukawa H. (2014) Crystal structure of a heterotetrameric NMDA receptor ion channel. Science 344: 992-7 [PMID:24876489]

71. Karakas E, Simorowski N and Furukawa H. (2011) Subunit arrangement and phenylethanolamine binding in GluN1/GluN2B NMDA receptors. Nature 475: 249-53 [PMID:21677647]

72. Kaur C, Sivakumar V and Ling EA. (2005) Expression of N-methyl-D-aspartate (NMDA) and alpha-amino-3-hydroxy-5-methyl-4-isoxazolepropionate (AMPA) GluR2/3 receptors in the developing rat pineal gland. J Pineal Res 39: 294-301 [PMID:16150111]

73. Kawahara Y, Kwak S, Sun H, Ito K, Hashida H, Aizawa H, Jeong SY and Kanazawa I. (2003) Human spinal motoneurons express low relative abundance of GluR2 mRNA: an implication for excitotoxicity in ALS. J Neurochem 85: 680-9 [PMID:12694394]

74. Kayser MS and Dalmau J. (2016) Anti-NMDA receptor encephalitis, autoimmunity, and psychosis. Schizophr Res 176: 36-40 [PMID:25458857]

75. Keinänen K, Wisden W, Sommer B, Werner P, Herb A, Verdoorn TA, Sakmann B and Seeburg $\mathrm{PH}$. (1990) A family of AMPA-selective glutamate receptors. Science 249: 556-60 [PMID:2166337]

76. Kelleher E, Barry H, Cotter DR, Corvin A and Murphy KC. (2020) Autoantibodies and Psychosis. Curr Top Behav Neurosci 44: 85-123 [PMID:31292938]

77. Kew JN and Kemp JA. (2005) Ionotropic and metabotropic glutamate receptor structure and pharmacology. Psychopharmacology (Berl.) 179: 4-29 [PMID:15731895]

78. Khan MA, Houck DR, Gross AL, Zhang XL, Cearley C, Madsen TM, Kroes RA, Stanton PK, Burgdorf J and Moskal JR. (2018) NYX-2925 Is a Novel NMDA Receptor-Specific Spirocyclic- $\beta$ Lactam That Modulates Synaptic Plasticity Processes Associated with Learning and Memory. Int J Neuropsychopharmacol 21: 242-254 [PMID:29099938]

79. Kim M, Chiego DJ and Bradley RM. (2008) Ionotropic glutamate receptor expression in preganglionic neurons of the rat inferior salivatory nucleus. Auton Neurosci 138: 83-90 [PMID:18096442]

80. Koike M, Tsukada S, Tsuzuki K, Kijima H and Ozawa S. (2000) Regulation of kinetic properties of GluR2 AMPA receptor channels by alternative splicing. J Neurosci 20: 2166-74 [PMID:10704491]

81. Kulagowski JJ, Baker R, Curtis NR, Leeson PD, Mawer IM, Moseley AM, Ridgill MP, Rowley M, Stansfield I and Foster AC et al.. (1994) 3'-(Arylmethyl)- and 3'-(aryloxy)-3-phenyl-4hydroxyquinolin-2(1H)-ones: orally active antagonists of the glycine site on the NMDA receptor. J Med Chem 37: 1402-5 [PMID:8182696]

82. Kumar J and Mayer ML. (2013) Functional insights from glutamate receptor ion channel 
structures. Annu Rev Physiol 75: 313-37 [PMID:22974439]

83. Kuner T and Schoepfer R. (1996) Multiple structural elements determine subunit specificity of Mg2+ block in NMDA receptor channels. J Neurosci 16: 3549-58 [PMID:8642401]

84. Köhler M, Kornau HC and Seeburg PH. (1994) The organization of the gene for the functionally dominant alpha-amino-3-hydroxy-5-methylisoxazole-4-propionic acid receptor subunit GluR-B. J Biol Chem 269: 17367-70 [PMID:7545935]

85. Lachamp P, Balland B, Tell F, Crest M and Kessler JP. (2003) Synaptic localization of the glutamate receptor subunit GluR2 in the rat nucleus tractus solitarii. Eur J Neurosci 17: 892-6 [PMID:12603280]

86. Leeson PD, Carling RW, Moore KW, Moseley AM, Smith JD, Stevenson G, Chan T, Baker R, Foster AC and Grimwood S et al.. (1992) 4-Amido-2-carboxytetrahydroquinolines. Structureactivity relationships for antagonism at the glycine site of the NMDA receptor. J Med Chem 35: 1954-68 [PMID:1534584]

87. Lerma J. (2006) Kainate receptor physiology. Curr Opin Pharmacol 6: 89-97 [PMID:16361114]

88. Lerma J. (2011) Net(o) excitement for kainate receptors. Nat Neurosci 14: 808-10 [PMID:21709676]

89. Linja MJ and Visakorpi T. (2004) Alterations of androgen receptor in prostate cancer. J Steroid Biochem Mol Biol 92: 255-64 [PMID:15663988]

90. Liu Q and Wong-Riley MT. (2005) Postnatal developmental expressions of neurotransmitters and receptors in various brain stem nuclei of rats. J Appl Physiol 98: 1442-57 [PMID:15618314]

91. Liu SJ and Zukin RS. (2007) Ca2+-permeable AMPA receptors in synaptic plasticity and neuronal death. Trends Neurosci 30: 126-34 [PMID:17275103]

92. Lodge D. (2009) The history of the pharmacology and cloning of ionotropic glutamate receptors and the development of idiosyncratic nomenclature. Neuropharmacology 56: 6-21 [PMID:18765242]

93. Lomeli H, Mosbacher J, Melcher T, Höger T, Geiger JR, Kuner T, Monyer H, Higuchi M, Bach A and Seeburg PH. (1994) Control of kinetic properties of AMPA receptor channels by nuclear RNA editing. Science 266: 1709-13 [PMID:7992055]

94. Lu CR, Hwang SJ, Phend KD, Rustioni A and Valtschanoff JG. (2002) Primary afferent terminals in spinal cord express presynaptic AMPA receptors. J Neurosci 22: 9522-9 [PMID:12417676]

95. Lu CR, Willcockson HH, Phend KD, Lucifora S, Darstein M, Valtschanoff JG and Rustioni A. (2005) Ionotropic glutamate receptors are expressed in GABAergic terminals in the rat superficial dorsal horn. J Comp Neurol 486: 169-78 [PMID:15844209]

96. Madry C, Betz H, Geiger JR and Laube B. (2008) Supralinear potentiation of NR1/NR3A excitatory glycine receptors by Zn2+ and NR1 antagonist. Proc Natl Acad Sci USA 105: 12563-8 [PMID:18711142]

97. Malayev A, Gibbs TT and Farb DH. (2002) Inhibition of the NMDA response by pregnenolone sulphate reveals subtype selective modulation of NMDA receptors by sulphated steroids. $\mathrm{Br} J$ Pharmacol 135: 901-9 [PMID:11861317]

98. Martínez L, Nascimento AS, Nunes FM, Phillips K, Aparicio R, Dias SM, Figueira AC, Lin JH, Nguyen P, Apriletti JW, Neves FA, Baxter JD, Webb P, Skaf MS and Polikarpov I. (2009) Gaining ligand selectivity in thyroid hormone receptors via entropy. Proc Natl Acad Sci USA [PMID:19926848]

99. Mayer ML. (2006) Glutamate receptors at atomic resolution. Nature 440: 456-62 [PMID:16554805]

100. McKay S, Griffiths NH, Butters PA, Thubron EB, Hardingham GE and Wyllie DJ. (2012) Direct pharmacological monitoring of the developmental switch in NMDA receptor subunit composition using TCN 213, a GluN2A-selective, glycine-dependent antagonist. Br J Pharmacol 166: 924-37 [PMID:22022974]

101. McNamara JO, Eubanks JH, McPherson JD, Wasmuth JJ, Evans GA and Heinemann SF. (1992) Chromosomal localization of human glutamate receptor genes. J Neurosci 12: 2555-62 [PMID:1319477]

102. Meyerson JR, Kumar J, Chittori S, Rao P, Pierson J, Bartesaghi A, Mayer ML and Subramaniam S. (2014) Structural mechanism of glutamate receptor activation and desensitization. Nature 514: 328-34 [PMID:25119039]

103. Milstein AD and Nicoll RA. (2008) Regulation of AMPA receptor gating and pharmacology by TARP auxiliary subunits. Trends Pharmacol Sci 29: 333-9 [PMID:18514334]

104. Miu P, Jarvie KR, Radhakrishnan V, Gates MR, Ogden A, Ornstein PL, Zarrinmayeh H, Ho K, Peters D and Grabell J et al.. (2001) Novel AMPA receptor potentiators LY392098 and LY404187: effects on recombinant human AMPA receptors in vitro. Neuropharmacology 40: 976-83 [PMID:11406188]

105. Morley RM, Tse HW, Feng B, Miller JC, Monaghan DT and Jane DE. (2005) Synthesis and pharmacology of N1-substituted piperazine-2,3-dicarboxylic acid derivatives acting as NMDA receptor antagonists. J Med Chem 48: 2627-37 [PMID:15801853]

106. Mosbacher J, Schoepfer R, Monyer H, Burnashev N, Seeburg PH and Ruppersberg JP. (1994) A 
molecular determinant for submillisecond desensitization in glutamate receptors. Science 266: 1059-62 [PMID:7973663]

107. Nakagawa T. (2010) The biochemistry, ultrastructure, and subunit assembly mechanism of AMPA receptors. Mol Neurobiol 42: 161-84 [PMID:21080238]

108. Nakanishi N, Shneider NA and Axel R. (1990) A family of glutamate receptor genes: evidence for the formation of heteromultimeric receptors with distinct channel properties. Neuron 5: 569-81 [PMID:1699567]

109. Naur P, Hansen KB, Kristensen AS, Dravid SM, Pickering DS, Olsen L, Vestergaard B, Egebjerg J, Gajhede $M$ and Traynelis SF et al.. (2007) Ionotropic glutamate-like receptor delta2 binds Dserine and glycine. Proc Natl Acad Sci USA 104: 14116-21 [PMID:17715062]

110. Newman MP, Blum S, Wong RC, Scott JG, Prain K, Wilson RJ and Gillis D. (2016) Autoimmune encephalitis. Intern Med J 46: 148-57 [PMID:26899887]

111. Neyton J and Paoletti P. (2006) Relating NMDA receptor function to receptor subunit composition: limitations of the pharmacological approach. J Neurosci 26: 1331-3 [PMID:16452656]

112. Paoletti P. (2011) Molecular basis of NMDA receptor functional diversity. Eur J Neurosci 33: 1351-65 [PMID:21395862]

113. Paoletti P, Bellone C and Zhou Q. (2013) NMDA receptor subunit diversity: impact on receptor properties, synaptic plasticity and disease. Nat Rev Neurosci 14: 383-400 [PMID:23686171]

114. Paoletti P and Neyton J. (2007) NMDA receptor subunits: function and pharmacology. Curr Opin Pharmacol 7: 39-47 [PMID:17088105]

115. Peddie CJ, Davies HA, Colyer FM, Stewart MG and Rodríguez JJ. (2008) Colocalisation of serotonin2A receptors with the glutamate receptor subunits NR1 and GluR2 in the dentate gyrus: an ultrastructural study of a modulatory role. Exp Neurol 211: 561-73 [PMID:18439999]

116. Pedregal C, Collado I, Escribano A, Ezquerra J, Domínguez C, Mateo AI, Rubio A, Baker SR, Goldsworthy J and Kamboj RK et al.. (2000) 4-Alkyl- and 4-cinnamylglutamic acid analogues are potent GluR5 kainate receptor agonists. J Med Chem 43: 1958-68 [PMID:10821708]

117. Perrais D, Pinheiro PS, Jane DE and Mulle C. (2009) Antagonism of recombinant and native GluK3-containing kainate receptors. Neuropharmacology 56: 131-40 [PMID:18761361]

118. Perrais D, Veran J and Mulle C. (2010) Gating and permeation of kainate receptors: differences unveiled. Trends Pharmacol Sci 31: 516-22 [PMID:20850188]

119. Pinheiro P and Mulle C. (2006) Kainate receptors. Cell Tissue Res 326: 457-82 [PMID:16847640]

120. Plested AJ. (2011) Kainate receptor modulation by sodium and chloride. Adv Exp Med Biol 717: 93-113 [PMID:21713670]

121. Polgár E, Watanabe M, Hartmann B, Grant SG and Todd AJ. (2008) Expression of AMPA receptor subunits at synapses in laminae I-III of the rodent spinal dorsal horn. Mol Pain 4: 5 [PMID:18215271]

122. Potier MC, Spillantini MG and Carter NP. (1992) The human glutamate receptor cDNA GluR1: cloning, sequencing, expression and localization to chromosome 5. DNA Seq 2: 211-8 [PMID:1320959]

123. Prüss H. (2017) Postviral autoimmune encephalitis: manifestations in children and adults. Curr Opin Neurol 30: 327-333 [PMID:28234798]

124. Prüss H, Leubner J, Wenke NK, Czirják GÁ, Szentiks CA and Greenwood AD. (2015) Anti-NMDA Receptor Encephalitis in the Polar Bear (Ursus maritimus) Knut. Sci Rep 5: 12805 [PMID:26313569]

125. Puckett C, Gomez CM, Korenberg JR, Tung H, Meier TJ, Chen XN and Hood L. (1991) Molecular cloning and chromosomal localization of one of the human glutamate receptor genes. Proc Natl Acad Sci USA 88: 7557-61 [PMID:1652753]

126. Puyal J, Sage C, Demêmes D and Dechesne CJ. (2002) Distribution of alpha-amino-3-hydroxy-5methyl-4 isoazolepropionic acid and N-methyl-D-aspartate receptor subunits in the vestibular and spiral ganglia of the mouse during early development. Brain Res Dev Brain Res 139: 51-7 [PMID:12414093]

127. Radley JJ, Farb CR, He Y, Janssen WG, Rodrigues SM, Johnson LR, Hof PR, LeDoux JE and Morrison JH. (2007) Distribution of NMDA and AMPA receptor subunits at thalamo-amygdaloid dendritic spines. Brain Res 1134: 87-94 [PMID:17207780]

128. Ragnarson B, Ornung G, Grant G, Ottersen OP and Ulfhake B. (2003) Glutamate and AMPA receptor immunoreactivity in Ia synapses with motoneurons and neurons of the central cervical nucleus. Exp Brain Res 149: 447-57 [PMID:12677325]

129. Rampersad V, Elliott CE, Nutt SL, Foldes RL and Kamboj RK. (1994) Human glutamate receptor hGluR3 flip and flop isoforms: cloning and sequencing of the cDNAs and primary structure of the proteins. Biochim Biophys Acta 1219: 563-6 [PMID:7918660]

130. Ritter LM, Vazquez DM and Meador-Woodruff JH. (2002) Ontogeny of ionotropic glutamate receptor subunit expression in the rat hippocampus. Brain Res Dev Brain Res 139: 227-36 [PMID:12480137] 
131. Rodríguez-Moreno A and Sihra TS. (2007) Kainate receptors with a metabotropic modus operandi. Trends Neurosci 30: 630-7 [PMID:17981346]

132. Rubio ME. (2006) Redistribution of synaptic AMPA receptors at glutamatergic synapses in the dorsal cochlear nucleus as an early response to cochlear ablation in rats. Hear Res 216-217: 154-67 [PMID:16644159]

133. Sagot E, Pickering DS, Pu X, Umberti M, Stensbøl TB, Nielsen B, Chapelet M, Bolte J, Gefflaut T and Bunch L. (2008) Chemo-enzymatic synthesis of a series of 2,4-syn-functionalized (S)glutamate analogues: new insight into the structure-activity relation of ionotropic glutamate receptor subtypes 5, 6, and 7.J Med Chem 51: 4093-103 [PMID:18578478]

134. Sakai R, Swanson GT, Shimamoto K, Green T, Contractor A, Ghetti A, Tamura-Horikawa Y, Oiwa C and Kamiya H. (2001) Pharmacological properties of the potent epileptogenic amino acid dysiherbaine, a novel glutamate receptor agonist isolated from the marine sponge Dysidea herbacea. J Pharmacol Exp Ther 296: 650-8 [PMID:11160654]

135. Sakimura K, Bujo H, Kushiya E, Araki K, Yamazaki M, Yamazaki M, Meguro H, Warashina A, Numa S and Mishina M. (1990) Functional expression from cloned cDNAs of glutamate receptor species responsive to kainate and quisqualate. FEBS Lett 272: 73-80 [PMID:1699805]

136. Sakimura K, Morita T, Kushiya E and Mishina M. (1992) Primary structure and expression of the gamma 2 subunit of the glutamate receptor channel selective for kainate. Neuron 8: 267-74 [PMID:1310861]

137. Santiago AR, Hughes JM, Kamphuis W, Schlingemann RO and Ambrósio AF. (2008) Diabetes changes ionotropic glutamate receptor subunit expression level in the human retina. Brain Res 1198: 153-9 [PMID:18258217]

138. Schauwecker PE. (2003) Differences in ionotropic glutamate receptor subunit expression are not responsible for strain-dependent susceptibility to excitotoxin-induced injury. Brain Res $\mathrm{Mol}$ Brain Res 112: 70-81 [PMID:12670704]

139. Seeburg PH and Hartner J. (2003) Regulation of ion channel/neurotransmitter receptor function by RNA editing. Curr Opin Neurobiol 13: 279-83 [PMID:12850211]

140. Semkova I, Huemmeke M, Ho MS, Merkl B, Abari E, Paulsson M, Joussen AM and Plomann M. (2010) Retinal localization of the glutamate receptor GluR2 and GluR2-regulating proteins in diabetic rats. Exp Eye Res 90: 244-53 [PMID:19878674]

141. Small B, Thomas J, Kemp M, Hoo K, Ballyk B, Deverill M, Ogden AM, Rubio A, Pedregal C and Bleakman D. (1998) LY339434, a GluR5 kainate receptor agonist. Neuropharmacology 37: 12617 [PMID:9849663]

142. Smothers CT and Woodward JJ. (2007) Pharmacological characterization of glycine-activated currents in HEK 293 cells expressing N-methyl-D-aspartate NR1 and NR3 subunits. J Pharmacol Exp Ther 322: 739-48 [PMID:17502428]

143. Sobolevsky AI, Rosconi MP and Gouaux E. (2009) X-ray structure, symmetry and mechanism of an AMPA-subtype glutamate receptor. Nature 462: 745-56 [PMID:19946266]

144. Sommer B, Keinänen K, Verdoorn TA, Wisden W, Burnashev N, Herb A, Köhler M, Takagi T, Sakmann B and Seeburg PH. (1990) Flip and flop: a cell-specific functional switch in glutamateoperated channels of the CNS. Science 249: 1580-5 [PMID:1699275]

145. Sommer B, Köhler M, Sprengel R and Seeburg PH. (1991) RNA editing in brain controls a determinant of ion flow in glutamate-gated channels. Cell 67: 11-9 [PMID:1717158]

146. Sun H, Kawahara Y, Ito K, Kanazawa I and Kwak S. (2005) Expression profile of AMPA receptor subunit mRNA in single adult rat brain and spinal cord neurons in situ. Neurosci Res 52: 228-34 [PMID:15927724]

147. Sun W, Ferrer-Montiel AV, Schinder AF, McPherson JP, Evans GA and Montal M. (1992) Molecular cloning, chromosomal mapping, and functional expression of human brain glutamate receptors. Proc Natl Acad Sci USA 89: 1443-7 [PMID:1311100]

148. Szczesniak AM, Gilbert RW, Mukhida M and Anderson GI. (2005) Mechanical loading modulates glutamate receptor subunit expression in bone. Bone 37: 63-73 [PMID:15922681]

149. Talos DM, Fishman RE, Park H, Folkerth RD, Follett PL, Volpe JJ and Jensen FE. (2006) Developmental regulation of alpha-amino-3-hydroxy-5-methyl-4-isoxazole-propionic acid receptor subunit expression in forebrain and relationship to regional susceptibility to hypoxic/ischemic injury. I. Rodent cerebral white matter and cortex. J Comp Neurol 497: 42-60 [PMID:16680782]

150. Talos DM, Follett PL, Folkerth RD, Fishman RE, Trachtenberg FL, Volpe JJ and Jensen FE. (2006) Developmental regulation of alpha-amino-3-hydroxy-5-methyl-4-isoxazole-propionic acid receptor subunit expression in forebrain and relationship to regional susceptibility to hypoxic/ischemic injury. II. Human cerebral white matter and cortex. J Comp Neurol 497: 61-77 [PMID:16680761]

151. Tan PH, Yang LC, Chiang PT, Jang JS, Chung HC and Kuo CH. (2008) Inflammation-induced upregulation of ionotropic glutamate receptor expression in human skin. Br J Anaesth 100: 380-4 [PMID:18238837]

152. Todd AJ, Polgár E, Watt C, Bailey ME and Watanabe M. (2009) Neurokinin 1 receptor- 
expressing projection neurons in laminae III and IV of the rat spinal cord have synaptic AMPA receptors that contain GluR2, GluR3 and GluR4 subunits. Eur J Neurosci 29: 718-26 [PMID:19200070]

153. Tomita S. (2010) Regulation of ionotropic glutamate receptors by their auxiliary subunits. Physiology (Bethesda) 25: 41-9 [PMID:20134027]

154. Traynelis SF, Burgess MF, Zheng F, Lyuboslavsky P and Powers JL. (1998) Control of voltageindependent zinc inhibition of NMDA receptors by the NR1 subunit. J Neurosci 18: 6163-75 [PMID:9698310]

155. Traynelis SF, Wollmuth LP, McBain CJ, Menniti FS, Vance KM, Ogden KK, Hansen KB, Yuan H, Myers SJ and Dingledine R. (2010) Glutamate receptor ion channels: structure, regulation, and function. Pharmacol Rev 62: 405-96 [PMID:20716669]

156. Tse YC, Lai CH, Lai SK, Liu JX, Yung KK, Shum DK and Chan YS. (2008) Developmental expression of NMDA and AMPA receptor subunits in vestibular nuclear neurons that encode gravity-related horizontal orientations. J Comp Neurol 508: 343-64 [PMID:18335497]

157. Venkatesan A and Adatia K. (2017) Anti-NMDA-Receptor Encephalitis: From Bench to Clinic. ACS Chem Neurosci 8: 2586-2595 [PMID:29077387]

158. Wang C and Niu L. (2013) Mechanism of inhibition of the GluA2 AMPA receptor channel opening by talampanel and its enantiomer: the stereochemistry of the 4-methyl group on the diazepine ring of 2,3-benzodiazepine derivatives. ACS Chem Neurosci 4: 635-44 [PMID:23402301]

159. Wang YQ, Hu HJ, Cao R and Chen LW. (2005) Differential co-localization of neurokinin-3 receptor and NMDA/AMPA receptor subunits in neurons of the substantia nigra of C57/BL mice. Brain Res 1053: 207-12 [PMID:16038885]

160. Willcockson H and Valtschanoff J. (2008) AMPA and NMDA glutamate receptors are found in both peptidergic and non-peptidergic primary afferent neurons in the rat. Cell Tissue Res 334: 17-23 [PMID:18679721]

161. Williams M, Kowaluk EA and Arneric SP. (1999) Emerging molecular approaches to pain therapy. J Med Chem 42: 1481-500 [PMID:10229619]

162. Wyllie DJ, Livesey MR and Hardingham GE. (2013) Influence of GluN2 subunit identity on NMDA receptor function. Neuropharmacology 74: 4-17 [PMID:23376022]

163. Yelshanskaya MV, Singh AK, Narangoda C, Williams RSB, Kurnikova MG and Sobolevsky AI. (2020) Structural basis of AMPA receptor inhibition by trans-4-butylcyclohexane carboxylic acid. Br J Pharmacol [PMID:32959886]

164. Yoneyama M, Kitayama T, Taniura H and Yoneda Y. (2004) Immunohistochemical detection by immersion fixation with Carnoy solution of particular non-N-methyl-D-aspartate receptor subunits in murine hippocampus. Neurochem Int 44: 413-22 [PMID:14687606]

165. Yuzaki M. (2003) The delta2 glutamate receptor: 10 years later. Neurosci Res 46: 11-22 [PMID:12725908]

166. Zhang JP, Wei LC, Cao R and Chen LW. (2006) Differential co-expression of AMPA receptor subunits in substance $\mathrm{P}$ receptor-containing neurons of basal forebrain regions of C57/BL mice. Neurochem Int 49: 319-26 [PMID:16580093]

167. Zhou LM, Gu ZQ, Costa AM, Yamada KA, Mansson PE, Giordano T, Skolnick P and Jones KA. (1997) (2S,4R)-4-methylglutamic acid (SYM 2081): a selective, high-affinity ligand for kainate receptors. J Pharmacol Exp Ther 280: 422-7 [PMID:8996224] 